\title{
Dampak tata ruang kantor terhadap efektivitas kerja pegawai dinas pendidikan kota Bandung
} (Impact of office room on employee work effectiveness of education city Bandung)

\author{
Widi Anggraeni', Tjutju Yuniarsih ${ }^{2 *}$ \\ 1,2Program Studi Pendidikan Manajemen Perkantoran, \\ Fakultas Pendidikan Ekonomi dan Bisnis, Universitas Pendidikan Indonesia, \\ Jl. Dr. Setiabudhi, No. 229 Bandung, Jawa Barat Indonesia \\ Email: yuniarsih@upi.edu
}

\begin{abstract}
ABSTRAK
Penelitian ini bertujuan untuk menganalisis pengaruh tata ruang kantor terhadap efektivitas kerja pegawai dengan menggunakan metode survey. Teknik pengumpulan data dalam penelitian ini menggunakan angket dengan rentang skor antara 1 sampai 5 menggunakan model rating scale. Responden dalam penelitian ini adalah para pegawai Dinas Pendidikan Kota Bandung. Teknik analisis data menggunakan analisis regresi sederhana. Hasil penelitian diperoleh bahwa tata ruang kantor memiliki pengaruh positif terhadap efektivitas kerja pegawai. Oleh karena itu, efektivitas kerja pegawai dapat meningkat melalui adanya peningkatan kondisi tata ruang kantor.
\end{abstract}

Kata Kunci: tata ruang kantor, efektivitas kerja

\begin{abstract}
This study aims to analyze the effect of office spatial on work effectiveness of employees by using survey method. This study performed data collection by using a questionnaire with a range of scores 1 to 5. Respondents of the study consisted of the employees of the Office of Education of Bandung City. This study used simple regression analysis as the data analysis technique. The results reveal that the office spatial brings positive effects on the work effectiveness of employees. Therefore, the work effectiveness of employees can be improved through the improvement of office spatial conditions.
\end{abstract}

Keywords: Office Spatial, work effectiveness

\section{PENDAHULUAN}

Berdasarkan Undang-Undang Guru dan Dosen No. 14 tahun 2005 dalam dunia pendidikan tidak hanya membutuhkan para guru (pendidik) yang mempunyai kemampuan mengajar yang tinggi, namun juga memerlukan sumber daya manusia lain yang bergerak khusus di bidang pendidikan yaitu para pegawai (tenaga kependidikan) yang bekerja di Dinas Pendidikan. Mengingat bahwa Dinas Pendidikan memiliki tugas untuk melayani masyarakat dengan baik dalam bidang pendidikan, maka para pegawai dituntut untuk dapat bekerja dengan efektif dalam setiap pelaksanaan program kerjanya. Hal ini sejalan dengan pendapat dari Gibson (2012, hlm. 23-29) yaitu analisis kehidupan organisasi dilihat

* Corresponding author

Copyright ( 2017, EISSN 2656-4734 
dari tiga faktor utama, yaitu 1) perilaku (individu, kelompok, organisasi), 2) struktur (desain organisasi), dan 3) proses komunikasi dan pengambilan keputusan. Dengan adanya sumber daya manusia yang berkualitas dan memiliki kreativitas yang tinggi dalam bekerja, dapat dipastikan bahwa organisasi tersebut dapat menjalakan setiap program kerjanya dengan lancar dan efektif.

Stephen P. Robbins (1994, hlm. 85) menjelaskan bahwa efektivitas dapat diartikan sebagai tingkat pencapaian organisasi atas tujuan jangka pendek (tujuan) dan jangka panjang (cara). Menurut Supriyono dalam Luh Putu, dkk. (2014, hlm. 481) Efektivitas merupakan hubungan antara keluaran suatu pusat tanggung jawab dengan sasaran yang mesti dicapai, semakin besar kontribusi keluaran yang dihasilkan terhadap nilai pencapaian sasaran tersebut, maka dapat dikatakan efektif pula unit tersebut. Selanjutnya Susanto dalam Herlyna (2014, hlm. 1461), menyatakan bahwa:

"Efektivitas adalah informasi harus sesuai dengan kebutuhan pemakai dalam mendukung suatu proses bisnis, termasuk di dalam informasi tersebut harus disajikan dalam waktu yang tepat, format yang tepat sehingga dapat dipahami, konsisten dengan format sebelumnya, isinya sesuai dengan kebutuhan saat ini dan lengkap atau sesuai dengan kebutuhan saat ini dan lengkap atau sesuai dengan kebutuhan dan ketentuan".

Menurut Dadang Aziz Salim Kepala Sub. Bagian Umum dan Kepegawaian, dilihat dari hasil evaluasi tahunan mengenai capaian kerja pegawai saat ini umumnya kinerja para pegawai di Dinas Pendidikan Kota Bandung masih belum optimal, oleh karena itu Dinas Pendidikan Kota Bandung sedang mencari penyebab dan meneliti berbagai kebutuhan yang diperlukan oleh para pegawai agar menjadi motivasi para pegawai untuk bekerja lebih produktif sehingga dapat memberikan hasil kerja yang optimal, sehingga dapat tercapai efektivitas kerja pegawai seperti yang diharapkan.

Adanya ketidakstabilan dan belum optimalnya hasil capaian kerja para pegawai ini dapat disebabkan oleh berbagai faktor, baik internal maupun eksternal. Faktor eksternal yang dapat berpengaruh pada hasil kerja pegawai diantaranya ada faktor lingkungan fisik dan faktor lingkungan sosial. Faktor lingkungan fisik dan sosial akan memberikan pengaruh pada pegawai berupa kenyamanan bekerja. Lingkungan fisik atau lingkungan kerja memiliki peranan penting bagi sebuah perusahaan atau instansi. Hal ini sejalan dengan yang dikemukakan oleh Ahyari (1994, hlm. 122) "Lingkungan kerja yang memotivasi bagi karyawan perusahaan yang bersangkutan akan dapat meningkatkan gairah kerja. Lingkungan kerja yang dapat memotivasi para karyawan perusahaan akan mendorong para karyawan untuk bekerja dengan sebaik-baiknya, sehingga pelaksanaan proses produksi di dalam perusahaan tersebut akan dapat berjalan dengan baik pula."

Salah satu contoh dari faktor lingkungan fisik yang dapat mempengaruhi kenyamanan pegawai saat bekerja ialah ruang kantor. Ruangan kantor ialah lingkungan fisik yang berhubungan secara langsung dengan pegawai, karena di ruangan kantor inilah para pegawai menghabiskan waktu bekerja dan mengerjakan berbagai tugas yang dimilikinya.

Hal ini sejalan dengan pendapat menurut Mariam, dkk. (2014, hlm. 48) bahwa: "Salah satu faktor yang mempengaruhi keberhasilan kinerja staf di kantor adalah faktor office layout atau tata ruang kantor yang meliputi pengaturan perabotan dan mesin yang digunakan ketika bekerja."

Berdasarkan hal tersebut rumusan masalah dari penelitian ini adalah "adakah pengaruh tata ruang kantor terhadap efektivitas kerja pegawai?”. Dengan demikian tujuan 
penelitian ini adalah untuk menganalisis pengaruh tata ruang kantor terhadap efektivitas kerja pegawai.

\section{TINJAUAN PUSTAKA}

\section{Efektivitas Kerja Pegawai}

Efektivitas merupakan hal yang sangat penting dalam sebuah perusahaan, karena proses tercapainya tujuan atau target perusahaan dipengaruhi oleh efektif atau tidaknya para pegawai di perusahaan tersebut. Menurut Peter Drucker dalam T. Hani Handoko (2013, hlm. 7) efektivitas adalah melakukan pekerjaan yang benar (doing the right things), sedangkan efisiensi adalah melakukan pekerjaan dengan benar (doing things right).

Sedangkan menurut Ni Luh, dkk. (2013, hlm.1): "Secara umum, efektivitas dapat diartikan sebagai kemampuan organisasi untuk melakukan tugas pokoknya sesuai dengan waktu yang telah ditetapkan. Setiap proses kegiatan dan kelembagaan diarahkan untuk menghasilkan sesuatu benar-benar sesuai dengan kebutuhan melalui pemanfaatan yang sebaikbaiknya dengan berbagai sumber yang tersedia."

Menurut T. Hani Handoko (2013, hlm. 7) efektivitas merupakan kemampuan untuk memilih tujuan yang tepat atau peralatan yang tepat untuk pencapaian tujuan yang telah ditetapkan. Dengan kata lain, seorang manajer efektif dapat memilih pekerjaan yang harus dilakukan atau metode (cara) yang tepat untuk mencapai tujuan.

Dari berbagai definisi di atas dapat disimpulkan bahwa efektivitas merupakan suatu konsep yang penting bagi sebuah organisasi, karena efektivitas dapat memberikan gambaran tingkat keberhasilan suatu organisasi dalam mencapai target atau tujuan yang telah ditetapkan sebelumnya melalui berbagai kegiatan yang telah dilaksanakan.

Beberapa ahli berpendapat mengenai indikator pengukuran efektivitas kerja pegawai, salah satu diantaranya ialah Sedarmayanti (2001, hlm. 58) bahwa efektivitas kerja pegawai dapat diukur melalui tiga indikator yaitu kualitas kerja, kuantitas kerja, dan waktu kerja.

\section{Tata Ruang Kantor}

Penn, et al. (dalam Leah R. Wolfeld 2010, hlm. 3) berpendapat bahwa: "Layout of a workplace affects how employees move about the office. On a basic level, the office layout can create a connected, interactive space or can separate work areas. By administering a survey investigating the frequency of contact with the employees in spatially isolated workspaces. I found that employees are more likely to interact with their coworkers in spaces that are more accessible." (Tata ruang berdampak pada bagaimana karyawan dapat bergerak di ruangan tersebut. Pada dasarnya, tata ruang kantor dapat menciptakan sebuah ruang interaktif yang terhubung atau area kerja terpisah. Dengan melakukan penelitian dan investigasi di ruangan kerja tertutup saya menemukan bahwa para karyawan dapat lebih mungkin berinteraksi dengan rekan kerjanya di ruangan kerja yang mudah diakses.)

Tisnaadmidjaja (2008) dalam Zerry Febryan, dkk. (2016, hlm. 193-208) menyatakan bahwa "Ruang adalah wujud fisik wilayah dalam dimensi geografis dan geometris yang merupakan wadah bagi manusia dalam melaksanakan kegiatan kehidupannya dalam suatu kualitas kehidupan yang layak. Sedangkan penataan ruang adalah suatu sistem proses perencanaan tata ruang, pemanfaatan tata ruang dan pengendalian pemanfaatan ruang."

Sedarmayanti (dalam Zaid Habibie 2013, hlm. 3) menyatakan bahwa "Tata ruang kantor adalah pengaturan dan penyusunan seluruh mesin kantor, alat perlengkapan kantor, 
serta perabot kantor pada tempat yang tepat, sehingga pegawai dapat bekerja dengan baik, nyaman, leluasa dan bebas untuk bergerak, sehingga tercapai efisiensi kerja."

Berdasarkan uraian di atas dapat ditarik kesimpulan bahwa tata ruang kantor merupakan upaya pengaturan dan penyusunan seluruh peralatan dan perlengkapan kantor pada tempat yang tepat agar para pegawai dapat bekerja dengan baik dan memiliki rasa kenyamanan yang tinggi sehingga dapat tercapainya efektivitas dan efisiensi kerja pegawai.

Sedarmayanti dan Eko (2014, hlm. 502) menyatakan bahwa fungsi tata ruang kantor tidak hanya menempatkan perlengkapan dan peralatan pada suatu kantor, tetapi tata ruang kantor harus dapat digunakan untuk mengatur dan memudahkan pergerakkan alur kerja pegawai dari satu ruangan ke ruangan lain.

Menurut Sedarmayanti (2011, hlm. 28) untuk mengukur kondisi baik atau tidaknya penataan suatu kantor dapat diukur melalui sebelas indikator yaitu 1) penerangan/cahaya; 2) temperatur/suhu; 3) kelembaban; 4) sirkulasi udara; 5) kebisingan; 6) getaran mesin; 7) bau-bauan; 8) tata warna; 9) dekorasi; 10) musik; 11) dan keamanan yang ada di tempat kerja.

\section{METODE PENELITIAN}

Penelitian ini dilakukan dengan mengunakan metode survey. Nazir (2013, hlm. 56) menjelaskan pengertian metode penelitian survey adalah:"Penyelidikan yang diadakan untuk memperoleh fakta-fakta dari gejala-gejala yang ada dan mencari keteranganketerangan secara faktual, baik tentang institusi sosial, ekonomi, atau politik dari suatu kelompok ataupun suatu daerah."

Metode ini digunakan untuk mengumpulkan informasi melalui angket. Teknik pengumpulan data menggunakan model rating scale yang dengan rentang antara 1 sampai 5 dengan responden penelitian yang berjumlah 62 orang di Dinas Pendidikan Kota Bandung.

Instrumen pengumpulan data terdiri atas dua (2) bagian yaitu angket untuk mengukur kondisi tata ruang kantor terdiri dari 11 indikator, yaitu penerangan, temperatur, kelembaban, sirkulasi udara, kebisingan, getaran mesin, bau-bauan/aroma, tata warna,dekorasi, musik, dan keamanan. Serta angket untuk mengukur tingkat efektivitas kerja pegawai yang terdiri atas tiga (3) indikator yaitu kualitas kerja, kuantitas kerja, dan waktu kerja.

Gambaran dari tanggapan responden mengenai kondisi tata ruang kantor dan tingkat efektivitas kerja pegawai diperoleh dengan statistik deskriptif mengunakan skor rata-rara tiap bagian. Kemudian teknik analisis untuk menguji hipotesis penelitian menggunakan analisis regresi.

\section{HASIL PENELITIAN DAN PEMBAHASAN \\ Tata Ruang Kantor}

Berdasarkan jawaban responden terhadap angket yang telah disebarkan, hasil yang diperoleh skor rata-rata variabel tata ruang kantor sebesar 3,43. Hal ini menunjukkan bahwa kondisi tata ruang kantor di Dinas Pendidikan Kota Bandung dipersepsi baik oleh para pegawai. Skor rata-rata hasil jawaban responden terhadap masing-masing indikator dapat dilihat pada tabel berikut.

Tabel 1.

Deskripsi Tata Ruang Kantor 
Jurnal Pendidikan Manajemen Perkantoran, Vol. 2, No. 2, Juli 2017

\begin{tabular}{|l|c|c|}
\hline \multicolumn{1}{|c|}{ Indikator } & Rata-rata & Penafsiran \\
\hline Penerangan/cahaya & 3,54 & Baik \\
\hline Temperatur/suhu & 3,52 & Baik \\
\hline Kelembaban & 3,45 & Baik \\
\hline Sirkulasi udara & 3,47 & Baik \\
\hline Kebisingan & 3,49 & Baik \\
\hline Getaran Mekanis & 3,3 & Sedang \\
\hline Aroma & 3,56 & Baik \\
\hline Tata Warna & 3,24 & Sedang \\
\hline Dekorasi & 3,4 & Baik \\
\hline Musik & 3,31 & Sedang \\
\hline Keamanan & 3,48 & Baik \\
\hline \multicolumn{1}{|c|}{ Rata-rata } & 3,43 & Baik \\
\hline
\end{tabular}

Sumber: Hasi Pengolahan Data

Apabila dihubungkan dengan tabel skala penafsiran deskripsi dari setiap skor, persepsi terhadap kondisi tata ruang kantor berada pada kategori baik. Skor tertinggi berada pada indikator aroma yaitu 3,56. Hal ini menunjukkan bahwa aroma yang berada di masing-masing ruang kerja dipersepsi sudah baik dan harum. Sedangkan skor terendah berada pada indikator tata warna yaitu 3,24. Tata warna yang ada di ruang kerja berada dalam kategori sedang. Hal ini menunjukkan bahwa meskipun kondisi tata ruang kantor sudah dipersepsi baik, namun para pegawai masih merasa bahwa pemilihan warna mebeuler yang digunakan belum dapat menimbulkan gairah kerja dan memberikan kesan rileks.

Efektivitas Kerja Pegawai

Berdasarkan jawaban responden terhadap angket yang telah disebarkan, diperoleh skor rata-rata untuk variabel efektivitas kerja pegawai sebesar 3,69. Hal ini menunjukkan bahwa tingkat efektivitas kerja pegawai di Dinas Pendidikan Kota Bandung dipersepsi tinggi oleh para responden. Skor rata-rata hasil jawaban responden terhadap masingmasing indikator dapat dilihat pada tabel berikut.

Tabel 2.

Deskripsi Efektivitas Kerja Pegawai

\begin{tabular}{|c|c|c|}
\hline Indikator & Rata-rata & Penafsiran \\
\hline Kualitas Kerja & 3,71 & Tinggi \\
\hline Kuantitas Kerja & 3,49 & Tinggi \\
\hline Waktu Kerja & 3,87 & Tinggi \\
\hline Rata-rata & 3,69 & Tinggi \\
\hline
\end{tabular}

Sumber: Hasi Pengolahan Data

Apabila dihubungkan dengan tabel skala penafsiran deskripsi dari setiap skor, ini menunjukkan tingkat efektivitas kerja pegawai berada pada kategori tinggi. Skor tertinggi berada pada indikator waktu kerja yaitu 3,87. Hal ini menunjukkan bahwa para responden beranggapan dapat datang dan pulang kantor sesuai waktu yang ditetapkan serta dapat menyelesaikan tugas tepat pada waktunya. Sedangkan skor terendah berada pada indikator kuantitas kerja yaitu 3,49. Hal ini menunjukkan bahwa meskipun tingkat efektivitas kerja 
sudah dipersepsi tinggi, para pegawai masih beranggapan bahwa hasil kerja nya belum optimal karena belum sesuai dengan target yang telah ditetapkan. Faktor yang mempengaruhi diantaranya kemampuan para pegawai dalam menyelesaikan tugasnya masih kurang, serta sarana dan prasarana perusahaan yang belum mendukung sehingga mengakibatkan belum tercapainya target hasil kerja dan adanya kegagalan produk atau layanan yang diberikan oleh para pegawai.

Efektivitas Kerja Pegawai sebagai Dampak dari Tata Ruang Kantor

Persamaan regresi linier sederhana untuk hipotesis variabel tata ruang kantor terhadap efektivitas kerja pegawai adalah adalah $\hat{Y}=14,915+0,720(X)$. Tanda positif $(+)$ menunjukkan hubungan antara variabel bebas dengan variabel terikat berjalan satu arah, sehingga apabila semakin tinggi kondisi tata ruang kantor, maka semakin tinggi tingkat efektivitas kerja pegawai dan begitupun sebaliknya. Uji hipotesis, diperoleh nilai Fhitung lebih besar dari nilai Ftabel yaitu 36,6822 > 4,0012 dengan dengan tingkat kesalahan $\alpha=$ $0,05 \mathrm{dan} \mathrm{dk}$ reg $\mathrm{b} / \mathrm{a}=1 \mathrm{dan} \mathrm{dk}$ res $=\mathrm{n}-2=60$. Nilai koefisien determinasi $\mathrm{KD}=\mathrm{r}^{2} \mathrm{x}$ $100 \%=(0,4953)^{2} \times 100 \%=24,5 \%$. Berdasarkan nilai koefisien determinasi, terbukti bahwa tata ruang kantor berpengaruh terhadap efektivitas kerja pegawai sebesar $24,5 \%$ sedangkan $75,5 \%$ sisanya dipengaruhi oleh faktor lain yang tidak tercakup dalam penelitian ini.

Hasil ini sejalan dengan pendapat Sedarmayanti (2011, hlm. 28) keadaan lingkungan kerja yang kurang baik dapat menuntut tenaga dan waktu yang lebih banyak dan tidak mendukung diperolehnya rancangan sistem kerja yang efisien dan efektif.

Sejalan dengan itu, Cahyana, Fradesa. Dewi (2016, hlm. 1) menyatakan bahwa tata ruang kantor yang baik akan memberikan manfaat antara lain arus pekerjaan akan berjalan lancar, yaitu lalu lintas kantor lebih baik, mempermudah pengawasan, dapat mendatangkan suasana kerja yang menyenangkan dan mengurangi ketegangan yang akhirnya dapat membangkitkan semangat etos kerja dan selanjutnya meningkatkan efisiensi dan efektivitas kerja.

\section{KESIMPULAN}

Efektivitas kerja pegawai di Dinas Pendidikan Kota Bandung dapat dilihat dari berbagai data, diantaranya data hasil capaian kerja pegawai. Berdasarkan data tersebut dapat dilihat bahwa capaian kerja para pegawai belum optimal.

Efektivitas kerja pegawai diukur melalui 3 indikator yaitu kualitas kerja, kuantitas kerja, dan waktu kerja. Berdasarkan hasil perhitungan skor rata-rata efektivitas kerja pegawai berada pada kategori tinggi.

Kondisi tata ruang kantor di Dinas Pendidikan Kota Bandung dipersepsi baik oleh para pegawai. Kondisi tata ruang kantor diukur melalui 11 indikator yaitu penerangan/cahaya, temperatur/suhu, kelembaban, sirkulasi udara, kebisingan, getaran mesin, aroma, tata warna, dekorasi, musik, dan keamanan. Berdasarkan hasil perhitungan skor rata-rata kondisi tata ruang kantor berada pada kategori baik.

Tata ruang kantor memiliki pengaruh yang positif terhadap efektivitas kerja pegawai. Hal ini menunjukkan, bahwa jika kondisi tata ruang kantor ditingkatkan maka efektivitas kerja pegawai pun akan meningkat, begitupun sebaliknya.

Bagi peneliti selanjutnya, diharapkan ada kajian lebih mendalam terhadap efektivitas kerja pegawai dengan faktor-faktor mencari lain yang tidak ada dalam penelitian ini. 


\section{DAFTAR PUSTAKA}

Ahyari, Agus. (1994). Manajemen Produksi. Yogyakarta: BPFE UGM.

Cahyana Fradesa, Dewi. (2016). Pengaruh Tata Ruang Kantor Terhadap Efektivitas Kerja Pegawai Pada Kantor Kesatuan Bangsa Dan Politik Kabupaten Kutai Timur. eJournal UNTAG. Vol.4 No.4. [Online]. Tersedia: ejournal.untag-smd-ac-id. [27 Mei 2017]

Febryan, Zerry. dkk. (2016). Evaluasi Tentang Penataan Ruang Dan Perumahan Pada Dinas Pekerjaan Umum Kabupaten Kutai Barat.eJournal Administrative Reform.Vol. 4, No. 2, hlm.193-203.

Gibson, et al. (2012).Organizations: Behaviour, structure, processes, fourteenth edition. New York: The McGraw-Hill Companies, Inc.

Habibie Asnar, Zaid. (2013). Pengaruh Tata Ruang Kantor Terhadap Produktivitas Kerja Pegawai Di Pusat Kajian Dan Pendidikan Dan Pelatihan Aparatur Iii Lembaga Administrasi Negara (PKP2A III Lan) Samarinda.eJournal Ilmu Pemerintahan. Vol. 1, No. 4, Hlm. 1488-1500. [Online]. Tersedia: ejournal.unesa.ac.id/article/12393/55/article.pdf.

[30 Januari 2017]

Handoko, T. Hani. (2013). Manajemen. Yogyakarta : BPFEE (edisi kedua)

Herlyna. (2014). Studi Tentang Efektivitas kerja Pegawai di Badan Kepegawaian Daerah Kalimantan Timur.eJournal FISIP UNMUL . Vol. 4.No. 2. Hlm. 1459 - 1472 .[Online]. Tersedia: http://ejournal.an.fisipunmul.ac.id/site/wpcontent/uploads/2014/09/Jurnal\%20Herlyna\%20(09-18-14-0439-04).pdf [30 Januari 2017]

Mariam, Iis. dkk. (2014).Implementasi Tata Ruang Kantor Dalam Mewujudkan Produktivitas Kerja Pegawai Pada PT Telekomunikasi Selular (Telkomsel).Epigram.Vol.1, No. 1, hlm.47-54.[Online]. Tersedia: http://lib.unnes.ac.id/22249/1/7101411360-s.pdf. [3 November 2016]

Moningka, Shinta Bonita. (2014). Efektivitas Kerja Pegawai Negeri Sipil Dalam Pelayanan Publik Di Kantor Kelurahan Kolongan Kecamatan Tomohon Tengah Kota Tomohon.eJournal UNSRAT. Vol. 1, No. 4, Hlm. 4961-4972.[Online]. Tersedia: http://ejournal.unsrat.ac.id/index.php/politico/article/view/5175/4691. [30 Januari 2017)

Luh, Putu Bakti Mesha, dkk.(2013). Pengaruh Motivasi Dan Disiplin Terhadap Efektivitas Kerja Karyawan. Jurnal Administrasi Bisnis. Vol. 6 .No. 2. Hlm. 1-8

Nazir, Moh. (2013). Metode Penelitian.Bogor: Ghalia Indonesia.

Robbins, Stephen P. (1994). Teori Organisasi: Struktur, Desain dan Aplikasi..Diterjemahkan oleh Jusuf Udaya, Lic., Ec. Jakarta: Arcan.

Sedarmayanti (2011).Tata Kerja dan Produktivitas Kerja.Bandung: CV Mandar Maju. 
Sedarmayanti, dkk.(2014). Pengaruh Tata Ruang Kantor Terhadap Kinerja Pegawai Dinas Tenaga Kerja Transmigrasi Sosial Kota Cimahi.Jurnal Ilmu Administrasi.Vol. XI, No. 3, Hlm. 501-510

Sedarmayanti.(2001). Sumber Daya Manusia dan Produktivitas Kerja.Bandung: CV Mandar Maju.

Undang-Undang Guru dan Dosen No. 14 tahun 2005

Wolfeld, Leah R.. (2010). Effects Of Office Layout On Job Satisfaction, Productivity And Organizational Commitment As Transmitted Through Face-To-Face Interactions.Colonial Academic Alliance Undergraduate Research Journal.Vol.1, No. $8, \quad$ hlm.1-21. [Online]. Tersedia: http://publish.wm.edu/cgi/viewcontent.cgi?article=1023\&context=caaurj. $\quad[1$ Desember 2016] 